\title{
Genetic and pathogenic difference between Streptococcus agalactiae serotype la fish and human isolates
}

\author{
Chishih Chu', Pei-Yu Huang ${ }^{2}$, Hung-Ming Chen ${ }^{3}$, Ying-Hsiang Wang ${ }^{3}$, I-An Tsai ${ }^{2}$, Chih-Cheng Lu ${ }^{1}$ \\ and Che-Chun Chen ${ }^{2 *}$
}

\begin{abstract}
Background: Streptococcus agalactiae (GBS) is a common pathogen to infect newborn, woman, the elderly, and immuno-compromised human and fish. 37 fish isolates and 554 human isolates of the GBS in 2007-2012 were investigated in serotypes, antibiotic susceptibility, genetic difference and pathogenicity to tilapia.

Results: PCR serotyping determined serotype la for all fish GBS isolates and only in 3.2 \% (3-4.2 \%) human isolates. For fish isolates, all consisted a plasmid less than $6 \mathrm{~kb}$ and belonged to ST7 type, which includes mainly pulsotypes I and la, with a difference in a deletion at the largest DNA fragment. These fish isolates were susceptible to all antimicrobials tested in 2007 and increased in non-susceptibility to penicillin, and resistance to clindamycin and ceftriaxone in 2011. Differing in pulsotype and lacking plasmid from fish isolates, human serotype la isolates were separated into eight pulsotypes II-IX. Main clone ST23 included pulsotypes II and IIa (50\%) and ST483 consisted of pulsotype III. Human serotype la isolates were all susceptible to ceftriaxone and penicillin and few were resistant to erythromycin, azithromycin, clindamycin, levofloxacin and moxifloxacine with the resistant rate of $20 \%$ or less. Using tilapia to analyze the pathogenesis, fish isolates could cause more severe symptoms, including hemorrhage of the pectoral fin, hemorrhage of the gill, and viscous black and common scites, and mortality (>95\% for pulsotype I) than the human isolates (<30\%); however, the fish pulostype la isolate 912 with deletion caused less symptoms and the lowest mortality $(<50 \%)$ than pulsotype I isolates.
\end{abstract}

Conclusion: Genetic, pathogenic, and antimicrobial differences demonstrate diverse origin of human and fish serotype la isolates. The pulsotype la of fish serotype la isolates may be used as vaccine strains to prevent the GBS infection in fish.

Keywords: Streptococcosis, Streptococcus agalactiae (GBS), Pulsotype, MLST, Serotype, Tilapia

\section{Background}

Streptococcus are pathogenic to cause streptococcal disease for humans and animals. Among Streptococcus spp., Gram-positive Streptococcus agalactiae (group B streptococcus; GBS) is a normal human gastrointestinal and genitourinary flora. Therefore, GBS infect more commonly the vaginas of women, especially more prevalent in the pregnant woman than those of non-pregnant woman [1] and causes early-onset or late-onset sepsis

\footnotetext{
*Correspondence: chencc@mail.ncyu.edu.tw

²Department of Aquatic Biosciences, National Chiayi University, Chiayi 60004, Taiwan, ROC

Full list of author information is available at the end of the article
}

and meningitis in newborns. In fish, the major pathogenic species that cause streptococcosis are S. agalactiae (GBS), S. dysgalactiae, S. iniaee and Lactococcus garvieae, which also infect human. Multiplex PCR has been developed to differentiate these species and to identify serotypes [2], especially the GBS serotypes [3, 4].

Streptococcosis is an important disease in fish. After infection, fishes may suffer meningitis and septicemia in common [5]; however, other syndromes may be associated with fish species [6]. Streptococcal infection has been reported in rainbow trout in 1957 [7] and later on in various fishes, including $O$. aura $\times$ O. nilotica hybrid fish [8], Mugil cephalus L. [9], Anguilla japonica, Seriola 
quinqueradiata [10], Paralichthys olivaceus [11], Ictalurus punctatus [12], hybrid-striped bass (Morone chrysops $\times$ Morone saxatilis) [13], Sebastes schlegeli [6], Seriola dumerili and S. lalandi [14]. Using antibiotics to treat streptococcal infection in fish, resistance rate to erythromycin, clarithromycin, and azithromycin was less than $15 \%$ for fish isolates [15]. Recently, human GBS has gradually become resistant to clindamycin and erythromycin and differed in resistance rate among countries and sources $[16,17]$.

In GBS, pathogenicity to fish may be associated with serotypes. For examples, serotypes serotype Ia is more pathogenic than serotype III [18], serotype Ia and Ib more prevalent in seafood [19], serotype Ib in Queensland grouper and serotype II in wild fish and stingrays in Australia [20]. Genetic and plasmid variations may change the host virulence and specificity. As diverse genetic sources, plasmids have been found to carry genes for drug resistance and virulence in various streptococcal species [21-23]. Furthermore, GBS virulence to fish also depends on environmental conditions, such as temperature above $26{ }^{\circ} \mathrm{C}$ increases the GBS virulence to tilapia [24]. Recent study reported that an increase in temperature from 28 to $35^{\circ} \mathrm{C}$ cause near two-fold mortality in tilapia and regulate the gene expression, such as up-regulation of the proinflammatory genes for cyclooxygenase-2, Il- $1 \beta$ and TNF- $\alpha$ [25]. Recently, we reported the prevalence change in serotypes and mutations in GyrA and ParC causing fluoroquinolone resistance of GBS human isolates $[26,27]$. Genomic analysis of human and fish isolates suggest transfer of GBS between human and fish [28].

To investigate the possible zoonotic infection of GBS, serotypic, genomic and pathogenicity differences between human and fish GBS isolates collected from the diseased fishes in aquaculture farms and patients from nearby hospital.

\section{Methods}

\section{Bacterial isolates and biochemical identification}

Bacteria were isolated from diseased fishes, including mullet (Mugil cephalus), tilapia (Oreochromis hybrids), big-scale liza (Liza macrolepis), bass [Lates calcarifer (giant seaperch), Bidyanus bidyanus (silver perch), Lateolabrax japonicus (Japanese seaperch), Morone saxatilis (striped bass) and Scortum barcoo (Jade perch)] and other species [Thunnus albacares (yellowfin), Acanthopagrus schlegelii (blackhead seabream) and Epinephelus lanceolatus (brindle grouper)] in Lutsao, Dongshih, Yizhu, Budai and Puzih of Chiayi county and Kouhu of Yulin county, and Tainan County in 2007-2012. Bacterial species were identified by Gram-staining, catalase testing, the Rapid ID 32 STREP system (Bio-Mérieux Inc, France), and PCR amplification. 554 human isolates from 2007 to 2012 were identified in Chiayi Chang Gung Memorial Hospital
(CGMH) located at Puzih of Chiayi County near the center of the fish farms. This study was approved by the research ethics committee of CGMH (97-0077B and 993958B). The protocols for fish experiment were performed according to the guidelines of the Animal Use Protocol and the Institutional Animal Care and Use Committee (Protocol 97017) of the National Chiayi University.

\section{PCR identification of bacterial species and serotypes of GBS}

Single colony was taken into Brian Heart Infusion (BHI) broth and total DNA was purified from overnight bacterial cultures using the Genomic DNA purification kit (Quality Systems Inc., Taiwan). Primers for bacterial identification are listed in Additional file 1: Table S1 and were designed by the combination and modification of previous primers [29]. The 25- $\mu$ l PCR reaction mixture contained 1X PCR buffer, $0.2 \mathrm{mM}$ dNTPs, $1.5 \mathrm{mM}$ $\mathrm{MgCl}_{2}, 0.2 \mu \mathrm{M}$ primers, and $0.5 \mathrm{U}$ Taq DNA polymerase. The PCR conditions were as follows: predenaturation at $94{ }^{\circ} \mathrm{C}$ for $2 \mathrm{~min} ; 25$ cycles of denaturation at $94^{\circ}$ $\mathrm{C}$ for $30 \mathrm{~s}$, annealing at $55^{\circ} \mathrm{C}$ for $45 \mathrm{~s}$, and extension at $72{ }^{\circ} \mathrm{C}$ for $45 \mathrm{~s}$; and a final extension at $72{ }^{\circ} \mathrm{C}$ for $5 \mathrm{~min}$. Serotyping of the GBS isolates was performed according to methods described previously [4]. PCR products were separated by $0.5 \% \mathrm{TBE}$ and $1.5 \%$ agarose at $50 \mathrm{~V}$ for $1.5 \mathrm{~h}$. After staining with ethidium bromide, gel images were taken under ultraviolent light illumination.

\section{Antimicrobial susceptibility}

Antibiotics that are commonly used in treatment of fish and human infection included amoxicillin, azithromycin, ceftriaxone, clindamycin, doxycycline, erythromycin, florfenicol, levofloxacin, moxifloxacin, oxytetracycline, and tetracycline. After adjusting the bacterial concentration to a 0.5 McFarland standard, the susceptibilities to these antibiotics were determined by the disc method (BD BBL ${ }^{\mathrm{TM}}$ SensiDisc $^{\text {TM }}$; BD Diagnostics, Franklin Lakes, NJ, USA) and the guideline of CLSI standard [30]. Susceptibility to penicillin was measured by the disc method (BD $\mathrm{BBL}^{\mathrm{TM}}$ SensiDisc $^{\text {TM}}$; BD Diagnostics, Franklin Lakes, NJ, USA) and the Etest $^{\circ}$ (BioMérieux, Marcy-l'Etoile, France). Streptococcus pneumonia ATCC49619 was used as the reference strain.

\section{Genetic analysis of fish and human GBS serotype la isolates} The plasmid number was determined by the method of Kado and Liu [31] with a minor modification of the lysis buffer to $0.2 \mathrm{~N} \mathrm{NaOH}$ and $1.5 \%$ SDS and plasmid size was estimated using 6.6- and 50-kb plasmids of $S$. Choleraesuis strain OU7085. An 600-bp Sau3A plasmid DNA fragment from fish isolate 886 was cloned and sequenced. The genotype of each isolate was determined by PFGE analysis. Briefly, overnight bacteria were first embedded in $0.8 \%$ agarose. The plugs were treated with lysozyme and then $1 \mathrm{mg} / \mathrm{ml}$ proteinase $\mathrm{K}$ at $50{ }^{\circ} \mathrm{C}$. After 
washing with TE buffer, the plugs were digested with the restriction endonuclease SmaI. The macro-DNA fragments were separated by CHEF DRIII (BioRad, Taiwan) using a switching time of $4 \mathrm{~s} / 70 \mathrm{~s}, 120^{\circ}$, and $6 \mathrm{~V}$ for $18 \mathrm{~h}$ for the first step and then a switching time of $4 \mathrm{~s} / 70 \mathrm{~s}$, $120^{\circ}$, and $4 \mathrm{~V}$ for $6 \mathrm{~h}$. Strains with a banding pattern difference of more than three bands were designated different genotypes, and strains with at least one band difference were designated different subgenotypes [32]. MLST analysis of fish isolates were performed according to the methods described earlier [33] and sequence types (ST) were determined by the S. agalactiae MLST database (http://pubmlst.org/sagalactiae/).

\section{The virulence of human and fish GBS isolates to tilapia}

Seven fish isolates $(886,900,912,948,953-1,954$, and 1004) and seven human isolates (G91, G108, G110, and G116 of serotype Ia as well as G1, G78, and G102 of serotype III) were used to investigate the differences in pathogenicity to tilapia between these human and fish isolates. Six tilapia fishes with the size of 7-9 cm were randomly grouped. Each fish was intraperitoneally injected with approximately $1 \times 10^{8} \mathrm{cfu}$ bacteria, and a PBS injection was used as a control. The death number of each group was recorded for two weeks. In experiment I, we investigated the mortality rate and symptoms of human and fish isolates each group were recorded. In experiment II, we only determined the mortality for the isolates at14 days after inoculation.

\section{Results and discussion}

Broad-host-range GBS can infect humans, fish and other animals [34-36]. In Taiwan, Yulin and Chiayi counties are the major aquatic culture regions with bass, mullet and tilapia as the primary fish, in which L. garvieae and GBS are main pathogens. In this study, we analyzed genetic and pathogenic differences of the GBS isolates from a hospital and nearby cultured fish farms to investigate the possible zoonotic transmission of GBS between fish and human.

\section{Serotype distribution of S. agalactiae fish and human isolates}

All 37 S. agalactiae isolates were mainly isolated in 2011 and belonged to serotype Ia identified by Multiplex PCR (Fig. 1 and Table 1). These isolates were isolated from various important cultured fishes, mainly from tilapia (40.5\%), followed by bass (37.8\%), big scale liza (5.4\%), mullet (8.1\%), and other species (8.1\%) (Table 2). Among 554 human GBS isolates, these were only 20 serotype Ia isolates $(3.6 \%)$ with the prevalence of $3.8 \%$ $(7 / 185)$ in $2007,3.0 \%(5 / 169)$ in $2008,3.7 \%(3 / 81)$ in 2011 and $4.2 \%(5 / 119)$ in 2012 (Table 1). Serotype Ia isolates were collected mainly from urine $(65 \%, 13 / 20)$, followed by vagina and genital tract swab, and prefer to infecting female than male (13 vs. 7) (Table 3), suggesting that serotype Ia isolates were not the major serotype to infect human and less invasive. Next, we investigated the genetic relatedness and clonal dissemination of these serotype Ia isolates.

\section{Genotyping and MLST analysis of GBS human isolates}

Phylogenetic relations between serotype Ia human and fish isolates were investigated by three methods: PFGE, plasmid and MLST analysis. PFGE analysis of SmaIdigested macro-fragments determined that all fish isolates belonged to pulsotypes I (81.1\%), Ia (13.5\%), and
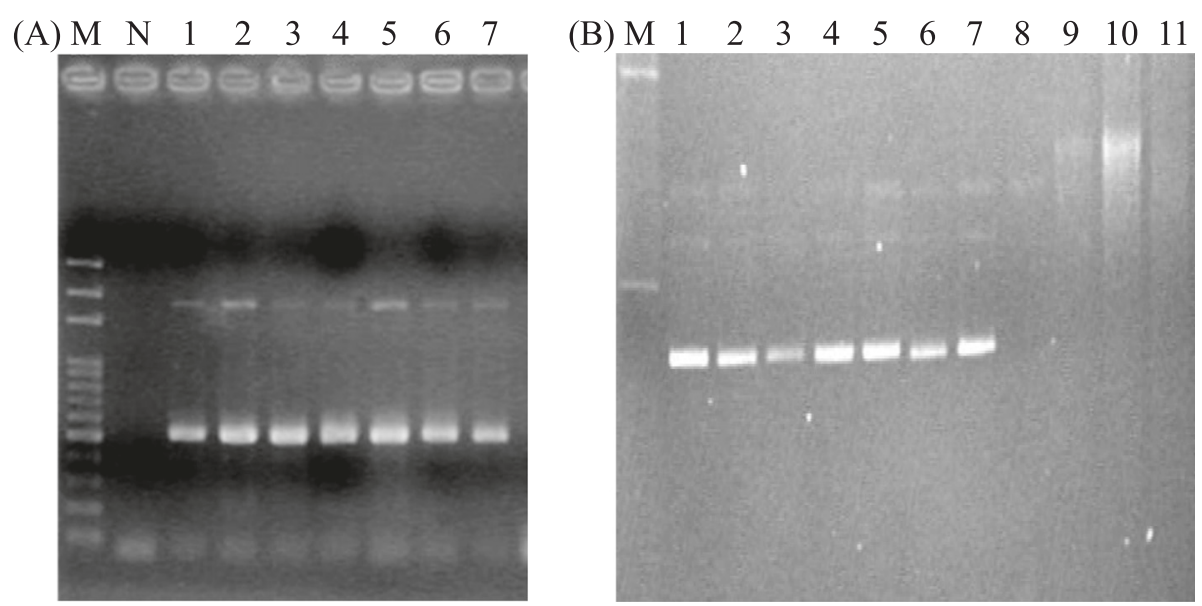

Fig. 1 Gel electrophoresis of multiplex PCR products for serotyping (a) and plasmids (b). A. M: 100 bp size marker, N: negative control, Line 1 to 7 are seven fish isolates 886, 900, 912, 948, 953-1, 954, and 1004. Amplicon sizes of serotype la are 1826 and 521 bp. B. M: 6.6 and 50 kb plasmids of Salmonella Choleraesuis isolate 7085. Lanes 1 to 7 are fish isolates 886, 948, 1004, 900, 912, 954, and 953-1. lane 8-11 are human isolates G91, G108, G110, and G115 
Table 1 Prevalence of human and fish Streptococcus agalactia serotype la isolates and their pulsotypes in four years

\begin{tabular}{|c|c|c|c|c|c|}
\hline Year & 2007 & 2008 & 2011 & 2012 & Total \\
\hline Total fish isolates & 7 & & 23 & 7 & 37 \\
\hline Serotype la [N (\%)] & $7(100)$ & & $23(100)$ & $7(100)$ & $37(100)$ \\
\hline \multicolumn{6}{|l|}{ Pulsotypes [N (\%)] } \\
\hline । & $6(85.7)$ & & 19 (82.6) & $5(71.4)$ & $30(81.1)$ \\
\hline la & $1(14.3)$ & & $4(17.4)$ & $0(0)$ & $5(13.5)$ \\
\hline ND & $0(0)$ & & $0(0)$ & $2(28.6)$ & $2(5.4)$ \\
\hline Total human isolates & 185 & 169 & 81 & 119 & 554 \\
\hline Serotype la [N (\%)] & $7(3.8)$ & $5(3.0)$ & $3(3.7)$ & $5(4.2)$ & $20(3.2)$ \\
\hline \multicolumn{6}{|l|}{ Pulsotypes [N (\%)] } \\
\hline$\|$ & $2(28.6)$ & $2(40)$ & $1(33.3)$ & $2(40)$ & $7(35)$ \\
\hline$\| \mathrm{a}$ & $2(28.6)$ & $2(40)$ & $1(33.3)$ & & $5(25)$ \\
\hline $11 \mathrm{~b}$ & $1(14.3)$ & & & & $1(5)$ \\
\hline III & $1(14.3)$ & & & & $1(5)$ \\
\hline IV & $1(14.3)$ & & & & $1(5)$ \\
\hline V & & $1(20)$ & & & $1(5)$ \\
\hline $\mathrm{VI}$ & & & $1(33.3)$ & & $1(5)$ \\
\hline VII & & & & $1(20)$ & $1(5)$ \\
\hline VIII & & & & $1(20)$ & $1(5)$ \\
\hline IX & & & & $1(20)$ & $1(5)$ \\
\hline
\end{tabular}

non-typable (5.4\%) and size difference between pulsotype I and Ia was observed in the largest DNA fragment, possibly a 200-kb difference (Fig. 2, Table 2). None of fish pulsotypes was identified in 20 human isolates, which were separated into nine pulsotypes II-IX with two major clones: pulsotypes II (5 isolates) and IIa (5 isolates) (Table 3). These results demonstrate clonal dissemination in fish and human isolates, which differed genetically. All fish isolates contained a plasmid smaller than $6 \mathrm{~kb}$, which was not observed in human isolates tested (Fig. 1, Table 4). Sequence analysis of a plasmid fragment identified a gene encoding plasmid recombination enzyme found in GBS (accession number $\mathrm{YP}_{-}$ 001586274 and EFV96312) and on 4.1-kb plasmid pER13 of Streptococcus thermophilus.

MLST analysis of the major pulsotypes of fish and human serotype Ia isolates identified that ST types differed between fish and human isolates: ST7 for all fish isolates, ST23 for human pulsotypes II and IIa and ST483 for pulsotype III (Table 3). ST7 is major

Table 2 Characterization of Streptococcus agalactiae fish isolates

\begin{tabular}{|c|c|c|c|c|c|c|c|c|c|c|}
\hline \multirow[t]{2}{*}{ Fish species } & \multirow[t]{2}{*}{ Place } & \multirow[t]{2}{*}{2007} & \multirow[t]{2}{*}{2011} & \multirow[t]{2}{*}{2012} & \multicolumn{3}{|c|}{ Number of each genotype } & \multicolumn{3}{|c|}{ Number of resistant isolates } \\
\hline & & & & & I & la & ND & Penicillin & Ceftriazone & Clindamycin \\
\hline \multirow[t]{2}{*}{ Mullet } & Chiayi & 1 & & 1 & $1 / 0 / 0^{a}$ & & $0 / 0 / 1$ & & & $0 / 0 / 0$ \\
\hline & Tainan & & 1 & & $0 / 1 / 0$ & & & $0 / 1 / 0$ & & \\
\hline \multirow[t]{2}{*}{ Tilapia } & Chiayi & 2 & 8 & 3 & $2 / 7 / 3$ & $0 / 1 / 0$ & & $0 / 4 / 0$ & & \\
\hline & Yunlin & 2 & & & $2 / 0 / 0$ & & & & & \\
\hline Big scale liza & Chiayi & & 1 & 1 & $0 / 1 / 0$ & & 0/0/1 & $0 / 0 / 1$ & & $0 / 0 / 1$ \\
\hline \multirow[t]{2}{*}{ Bass } & Chiayi & 1 & 9 & & 0/7/0 & $1 / 2 / 0$ & & $0 / 3 / 0$ & $0 / 1 / 0$ & \\
\hline & Yunlin & & 3 & 1 & $0 / 2 / 1$ & $0 / 1 / 0$ & & & & \\
\hline \multirow[t]{2}{*}{ Other species } & Chiayi & 1 & & 1 & $1 / 0 / 1$ & & & & & \\
\hline & Yunlin & & 1 & & $0 / 1 / 0$ & & & & & \\
\hline Total & & 7 & 23 & 7 & $6 / 19 / 5$ & $1 / 4 / 0$ & $0 / 0 / 2$ & $0 / 8 / 1$ & $0 / 1 / 0$ & 0/0/1 \\
\hline
\end{tabular}

${ }^{\mathrm{a}}$ 1/0/0 means one isolates in 2007, and 0 in 2011 and 2012 
Table 3 Characteristics of 20 Streptococcus agalactiae la human isolates

\begin{tabular}{|c|c|c|c|c|c|c|c|c|c|}
\hline \multirow[t]{2}{*}{ Strain } & \multirow[t]{2}{*}{ Year } & \multirow[t]{2}{*}{ Sex } & \multirow[t]{2}{*}{ Source ${ }^{a}$} & \multirow[t]{2}{*}{ Pulsotype } & \multicolumn{5}{|l|}{ Resistance to ${ }^{b}$} \\
\hline & & & & & Erythromycin & Azithromycin & Clindamycin & Levofloxacin & Moxifloxacin \\
\hline G15 & 2007 & M & $B$ & $\|$ & - & - & - & + & + \\
\hline G91 & 2007 & $\mathrm{~F}$ & $U$ & Ila & - & - & - & - & - \\
\hline G108 & 2007 & M & $U$ & Ila & - & - & - & - & - \\
\hline G110 & 2007 & $\mathrm{~F}$ & $U$ & III & + & + & + & - & - \\
\hline G116 & 2007 & M & $U$ & $\|$ & - & - & - & - & - \\
\hline G127 & 2007 & M & U & IV & - & - & - & - & - \\
\hline G176 & 2007 & M & $U$ & Ilb & - & - & - & - & - \\
\hline G233 & 2008 & $\mathrm{~F}$ & U & $\|$ & - & - & - & + & + \\
\hline G268 & 2008 & M & $U$ & V & - & - & - & - & - \\
\hline G335 & 2008 & $\mathrm{~F}$ & $U$ & Ila & - & - & - & - & - \\
\hline G340 & 2008 & $\mathrm{~F}$ & $U$ & Ila & - & - & - & - & - \\
\hline G349 & 2008 & $M$ & U & V & - & - & - & - & - \\
\hline G645 & 2011 & $\mathrm{~F}$ & OTH & II & - & - & - & - & - \\
\hline G649 & 2011 & $\mathrm{~F}$ & OTH & $\mathrm{VI}$ & + & + & + & - & - \\
\hline G656 & 2011 & $\mathrm{~F}$ & GTS & Ila & - & - & - & - & - \\
\hline G684 & 2012 & $\mathrm{~F}$ & GTS & IX & - & - & - & - & - \\
\hline G741 & 2012 & $\mathrm{~F}$ & U & $\|$ & - & - & - & - & - \\
\hline G764 & 2012 & $\mathrm{~F}$ & $U$ & II & - & - & - & - & - \\
\hline G772 & 2012 & $\mathrm{~F}$ & VA & VII & + & + & + & - & - \\
\hline G800 & 2012 & $\mathrm{~F}$ & VA & VIII & - & - & + & - & - \\
\hline \multicolumn{5}{|c|}{ Total resistant number [n (\%)] } & $3(15)$ & $3(15)$ & $4(20)$ & $2(10)$ & $2(10)$ \\
\hline
\end{tabular}

${ }^{a} B$ blood, $U$ urine, GTS genital tract swab, VA vagina, OTH others

$\mathrm{b}_{+}$: resistance, - : susceptible

pathogen to cause disease in tilapia in Asia and has been reported in isolates from tilapia and human [37]. Genetic differences in ST type, pulsotype and plasmid imply that human and fish isolates may vary in pathogenicity to tilapia.

\section{Antibiotic susceptibility of human and fish serotype la} isolates

Multidrug resistant isolates have emerged due to the intensive culture of fishes and antimicrobial misuse to control bacterial infection. The antimicrobial resistance

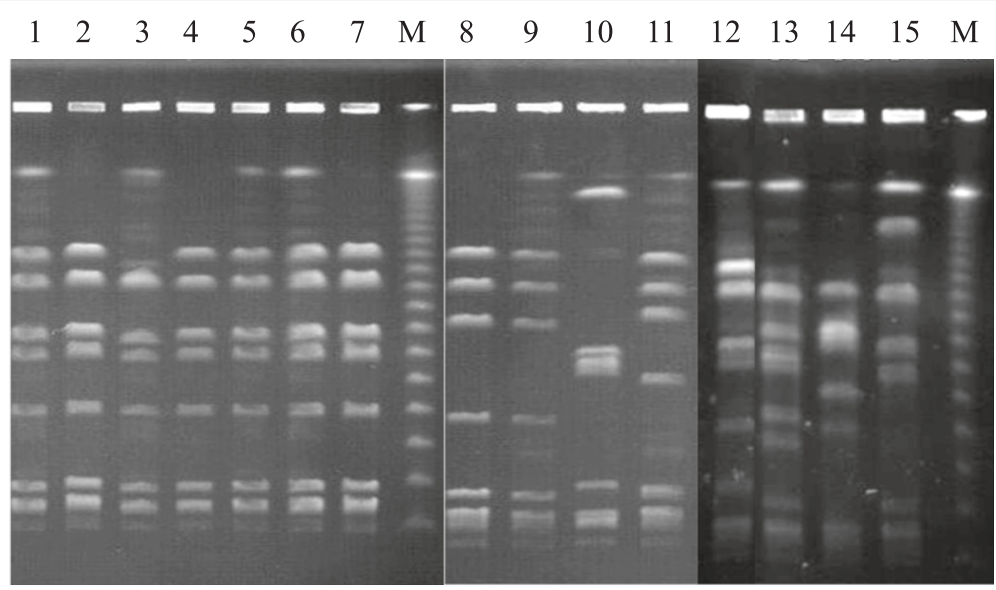

Fig. 2 Pulsed-field gel electrophoresis of Smal-digested macro-framents of S. agalactiae isolates. M: $\lambda$-DNA marker. Line 1-7 are fish isolates 886, $900,912,943,954,953-1$, and 1004. Line 8-15 are human isolates G91, G108, G110, and G116 of serotype la, G1 of serotype III, G12 of serotype V, G13 of serotype VI, and G14 of serotype Ib 
Table 4 Characterization of human and fish isolates for fish cytotoxitity test

\begin{tabular}{|c|c|c|c|c|c|c|c|c|}
\hline \multirow[t]{2}{*}{ Source } & \multirow[t]{2}{*}{ Strain } & \multirow[t]{2}{*}{ Serotype } & \multirow[t]{2}{*}{$\mathrm{MLST}^{\mathrm{a}}$} & \multirow[t]{2}{*}{ Pulsotype } & \multirow[t]{2}{*}{ Plasmid } & \multicolumn{3}{|l|}{ Resistance $^{\mathrm{b}}$ to } \\
\hline & & & & & & Erythromycin & Azithromycin & Clindamycin \\
\hline \multirow[t]{7}{*}{ Fish } & 886 & la & ST7 & I & + & - & - & - \\
\hline & 900 & & ST7 & 1 & + & - & - & - \\
\hline & 912 & & ST7 & la & + & - & - & - \\
\hline & 948 & & ST7 & 1 & + & - & - & - \\
\hline & $953-1$ & & ST7 & I & + & - & - & - \\
\hline & 954 & & ST7 & 1 & + & - & - & - \\
\hline & 1004 & & ST7 & 1 & + & - & - & - \\
\hline \multirow[t]{7}{*}{ Human } & G91 & la & ST23 & $\|$ & - & - & - & - \\
\hline & G108 & & ST23 & $\|$ & - & - & - & - \\
\hline & G110 & & ST483 & III & - & + & + & + \\
\hline & G116 & & ST23 & Ila & - & - & - & - \\
\hline & G1 & III & ND & $\mathrm{lb}$ & - & - & - & - \\
\hline & G78 & & ND & IV & - & + & + & + \\
\hline & G102 & & ND & V & - & + & + & + \\
\hline
\end{tabular}

${ }^{a} \mathrm{ND}$ : Non-determined. All isolates were collected in 2007

${ }^{b}+$ : resistance, - : susceptible

patterns of Streptococcus spp. differed among mammals, reptiles, amphibians and aquatic animals [15]. The antimicrobial resistance of Streptococcus isolates ranged from greater than $85 \%$ resistance to spiramycin, enrofloxacin, and clarithromycin to less than $60 \%$ resistance to erythromycin, azithromycin and amoxicillin. In this study, all fish isolates were susceptible to amoxicillin, doxycycline, oxytetracycline, florfenicol, levofloxacin, and moxifloxacin. Previously, it was reported that the disk diffusion methods using penicillin $G$ disks could not determine penicillin resistant GBS isolates [38]. Indeed, MIC (mg/L) for penicillin tested against $34.8 \%$ (8/ 23) isolates with penicillin resistance determined by disk method ranged from 0.16 to $0.23,0.47$, and 0.64 in 2011 compared to $0.25 \mathrm{mg} / \mathrm{L}$ of S. pneumonia ATCC49619 and only one isolate was resistance to ceftriaxone, clindamycin, and erythromycin. An increase of resistance to erythromycin of macrolide, clindamycin of lincosamide, and ceftriaxone and non-susceptible to penicillin that are commonly used in human may be needed to concern.

In compared to other serotypes, serotype Ia isolates were less resistance to antimicrobials tested and emerged resistance to levofloxacin and moxifloxacin [26]. The human GBS Ia isolates were sensitive to penicillin and ceftriaxone while human isolates were higher in resistance to azithromycin, clindamycin, and erythromycin than fish isolates (Tables 2 and 4). Simultaneous mutations in the quinolone resistance-determining regions of $\mathrm{gyr} A$ and $\operatorname{par} C$ were observed in two levofloxacin and moxifloxacin resistant isolates [27], which may be same clone from different patients with identical genotypes and antibiogram.

\section{Pathogenicity analysis of $\mathrm{S}$. agalactiae to tilapia}

In tilapia, GBS infection frequently causes meningoencephalitis with high mortality [39]. Such infection occurs while tilapia is over $20 \mathrm{~g}$ in weight and grows in the condition of broodstock on-growing and market fish [40]. Pathogenicity analysis to tilapia was performed using 14 fish and human isolates, which characteristics are listed in Table 4. Briefly, all seven fish isolates of pulsotypes I and Ia were almost identical genetically and sensitive to azithromycin, erythromycin, and clindamycin while seven human serotypes Ia and III differed in ST types, pulsotypes, and resistance to azithromycin, erythromycin, and clindamycin.

The symptom appearance in fish is strain- and serotypedependent. It has been reported that GBS serotype Ia isolates are more pathogenic to tilapia than serotype III isolates [18]. After infecting by GBS fish isolates, tilapia showed three primary symptoms that were viscous black and common ascites (25-91.7 \%) being the most prevalent, hemorrhage of the gill (8.3-58.3\%) and hemorrhage of the pectoral fin (8.3-50\%) (Table 5). Considering symptom prevalence in tilapia for fish isolates, pulsotype I isolate 900 was the most virulent, and pulsotype Ia isolate 912 was the least virulent. In human isolates, viscous black and common ascites, hemorrhage of the gill and hemorrhage of the pectoral fin were occasionally observed, for examples, only viscous black and common ascites in one fish infected by serotype Ia isolates G91, G108, and G110 and hemorrhage of the gill and hemorrhage of the pectoral fin infected by serotype G1.

Early reports demonstrated that fish and human isolates caused fish mortality differently. In contrast to the 
Table 5 Death and symptom number of tilapia response to seven serotype la fish isolates and seven serotype la and III human isolates

\begin{tabular}{|c|c|c|c|c|c|c|c|c|c|c|c|c|c|c|c|c|c|}
\hline \multirow{4}{*}{$\begin{array}{l}\text { Bacterial } \\
\text { Source }\end{array}$} & \multirow[t]{4}{*}{ Serotype } & \multirow[t]{4}{*}{ Strain } & \multirow[t]{4}{*}{ Repeat $^{a}$} & \multicolumn{9}{|c|}{ Symptom } & \multicolumn{5}{|c|}{ Mortality } \\
\hline & & & & \multicolumn{3}{|c|}{$\begin{array}{l}\text { Hemorrhage of } \\
\text { pectoral fin }\end{array}$} & \multicolumn{3}{|c|}{$\begin{array}{l}\text { Hemorrhage } \\
\text { of gill }\end{array}$} & \multicolumn{3}{|c|}{$\begin{array}{l}\text { Viscous black and } \\
\text { common ascites }\end{array}$} & \multicolumn{3}{|l|}{$\mathrm{a}^{\mathrm{a}}$} & \multicolumn{2}{|l|}{$\|^{\mathrm{b}}$} \\
\hline & & & & \multirow[t]{2}{*}{ No. } & \multicolumn{2}{|l|}{ Mean } & \multirow[t]{2}{*}{ No. } & \multicolumn{2}{|l|}{ Mean } & \multirow[t]{2}{*}{ No. } & \multicolumn{2}{|c|}{ Mean (\%) } & \multirow[t]{2}{*}{ No. } & \multicolumn{2}{|l|}{ Mean } & \multirow{2}{*}{$\begin{array}{l}\text { Bacterial dose } \\
\left(1 \times 10^{8} \mathrm{cfu}\right)\end{array}$} & \multirow[t]{2}{*}{ Mean (\%) } \\
\hline & & & & & No. & $\%$ & & No. & $\%$ & & & & & No. & $\%$ & & \\
\hline \multirow[t]{16}{*}{ Fish isolates } & Control & & 1 & $0 / 6$ & $0 / 6$ & 0 & $0 / 6$ & $0 / 6$ & 0 & $0 / 6$ & $0 / 6$ & 0 & $0 / 6$ & $0 / 6$ & 0 & 0 & $16.7 \pm 0$ \\
\hline & & & 2 & $0 / 6$ & & & $0 / 6$ & & & $0 / 6$ & & & $0 / 6$ & & & & \\
\hline & la & 886 & 1 & $0 / 6$ & $0.5 / 6$ & 8.3 & $2 / 6$ & $2.5 / 6$ & 41.7 & $5 / 6$ & $4 / 6$ & 66.7 & $6 / 6$ & $6 / 6$ & 100 & $3.1-3.8$ & $100 \pm 0$ \\
\hline & & & 2 & $1 / 6$ & & & $3 / 6$ & & & $3 / 6$ & & & $6 / 6$ & & & & \\
\hline & & 900 & 1 & $2 / 6$ & $3 / 6$ & 50 & $3 / 6$ & $3.5 / 6$ & 58.3 & $5 / 6$ & $5.5 / 6$ & 91.7 & $6 / 6$ & $6 / 6$ & 100 & $2.5-2.6$ & $100 \pm 0$ \\
\hline & & & 2 & $4 / 6$ & & & $4 / 6$ & & & $6 / 6$ & & & $6 / 6$ & & & & \\
\hline & & 912 & 1 & $0 / 6$ & $0.5 / 6$ & 8.3 & $0 / 6$ & $0.5 / 6$ & 8.3 & $2 / 6$ & $1.5 / 6$ & 25 & $5 / 6$ & $3.5 / 6$ & 58.3 & $2.1-3.1$ & $54.2 \pm 25.0$ \\
\hline & & & 2 & $1 / 6$ & & & $1 / 6$ & & & $1 / 6$ & & & $2 / 6$ & & & & \\
\hline & & 948 & 1 & $3 / 6$ & $2.5 / 6$ & 41.7 & $3 / 6$ & $2.5 / 6$ & 41.7 & $4 / 6$ & $4 / 6$ & 66.7 & $6 / 6$ & $5.5 / 6$ & 91.7 & $3.1-3.8$ & $91.7 \pm 16.7$ \\
\hline & & & 2 & $2 / 6$ & & & $2 / 6$ & & & $4 / 6$ & & & $5 / 6$ & & & & \\
\hline & & $953-1$ & 1 & $0 / 6$ & $1 / 6$ & 16.7 & $2 / 6$ & $1.5 / 6$ & 25 & $2 / 6$ & $1.5 / 6$ & 25 & $6 / 6$ & $6 / 6$ & 100 & $2.5-2.6$ & $100 \pm 0$ \\
\hline & & & 2 & $2 / 6$ & & & $1 / 6$ & & & $1 / 6$ & & & $6 / 6$ & & & & \\
\hline & & 954 & 1 & $0 / 6$ & $1 / 6$ & 16.7 & $3 / 6$ & $3 / 6$ & 50 & $6 / 6$ & $4.5 / 6$ & 75 & $6 / 6$ & $5 / 6$ & 83.3 & $2.1-3.1$ & $54.2 \pm 25.0$ \\
\hline & & & 2 & $2 / 6$ & & & $3 / 6$ & & & $3 / 6$ & & & $4 / 6$ & & & & \\
\hline & & 1004 & 1 & $1 / 6$ & $0.5 / 6$ & 8.3 & $1 / 6$ & $1 / 6$ & 16.7 & $5 / 6$ & $4 / 6$ & 0 & $6 / 6$ & $5 / 6$ & 83.3 & $2.1-3.4$ & $95.8 \pm 8.3$ \\
\hline & & & 2 & $0 / 6$ & & & $1 / 6$ & & & $3 / 6$ & & 0 & $4 / 6$ & & & & \\
\hline Human Isolate & Control & & 1 & $0 / 6$ & $0 / 6$ & 0 & $0 / 6$ & $0 / 6$ & 0 & $0 / 6$ & $0 / 6$ & 0 & $1 / 6$ & $1 / 6$ & 16.7 & 0 & $16.7 \pm 0$ \\
\hline & & & 2 & $0 / 6$ & & & $0 / 6$ & & & $0 / 6$ & & & $1 / 6$ & & & & \\
\hline & la & G91 & 1 & $0 / 6$ & $0 / 6$ & 0 & $0 / 6$ & $0 / 6$ & 0 & $1 / 6$ & $0.5 / 6$ & 8.3 & $1 / 6$ & $0.5 / 6$ & 8.3 & $2.3-2.9$ & $8.3 \pm 9.62$ \\
\hline & & & 2 & $0 / 6$ & & & $0 / 6$ & & & $0 / 6$ & & & $0 / 6$ & & & & \\
\hline & & G108 & 1 & $0 / 6$ & $0 / 6$ & 0 & $0 / 6$ & $0 / 6$ & 0 & $1 / 6$ & $0.5 / 6$ & 8.3 & $0 / 6$ & $0.5 / 6$ & 8.3 & $1.8-2.2$ & $16.7 \pm 13.6$ \\
\hline & & & 2 & $0 / 6$ & & & $0 / 6$ & & & $0 / 6$ & & & $1 / 6$ & & & & \\
\hline & & G110 & 1 & $0 / 6$ & $0 / 6$ & 0 & $0 / 6$ & $0 / 6$ & 0 & $0 / 6$ & $0.5 / 6$ & 8.3 & $1 / 6$ & $1 / 6$ & 16.7 & $2.1-3.0$ & $8.3 \pm 8.34$ \\
\hline & & & 2 & $0 / 6$ & & & $0 / 6$ & & & $1 / 6$ & & & $1 / 6$ & & & & \\
\hline & III & G116 & 1 & $0 / 6$ & $0 / 6$ & 0 & $0 / 6$ & $0 / 6$ & 0 & $0 / 6$ & $0 / 6$ & 0 & $2 / 6$ & $1 / 6$ & 16.7 & $1.9-2.6$ & $29.2 \pm 21.0$ \\
\hline & & & 2 & $0 / 6$ & & & $0 / 6$ & & & $0 / 6$ & & & $0 / 6$ & & & & \\
\hline & & G1 & 1 & $1 / 6$ & $0.5 / 6$ & 8.3 & $1 / 6$ & $0.5 / 6$ & 8.3 & $0 / 6$ & $0 / 6$ & 0 & $1 / 6$ & $0.5 / 6$ & 16.7 & $1.3-2.0$ & $16.7 \pm 13.6$ \\
\hline & & & 2 & $0 / 6$ & & & $0 / 6$ & & & $0 / 6$ & & & 0 & & & & \\
\hline & & G78 & 1 & $0 / 6$ & $0 / 6$ & 0 & $0 / 6$ & $0 / 6$ & 0 & $0 / 6$ & $0 / 6$ & 0 & 0 & $0 / 6$ & 16.7 & $1.4-1.9$ & $12.5 \pm 16.0$ \\
\hline & & & 2 & $0 / 6$ & & & $0 / 6$ & & & $0 / 6$ & & & 1 & & & & \\
\hline & & G102 & 1 & 0 & $0 / 6$ & 0 & $0 / 6$ & $0 / 6$ & 0 & $0 / 6$ & $0 / 6$ & 0 & 0 & $0.5 / 6$ & 16.7 & $1.3-2.1$ & $12.5 \pm 16.0$ \\
\hline & & & 2 & 0 & & & $0 / 6$ & & & $0 / 6$ & & & 0 & & & & \\
\hline
\end{tabular}

contention that human isolates are more lethal than fish isolates $\left(\mathrm{LD}_{50}=10^{6} \mathrm{CFU} /\right.$ per fish for human isolates vs. $\mathrm{LD}_{50}=6.1 \times 10^{7} \sim 1.94 \times 10^{8} \mathrm{cfu} /$ per fish for fish isolates) [41], fish isolates were more lethal to tilapia than cattle or human isolates at low $\operatorname{LD}_{50}[24,37]$. With a bacterial dose of $2.1 \sim 3.8 \times 10^{8} \mathrm{cfu}$ for fish isolates and $1.3 \sim$ $3.0 \times 10^{8} \mathrm{cfu}$ for human isolates in this study, the mortality rate of tilapia was, on average, below $50 \%$ for fish isolate 912 and over $95 \%$ for the remaining fish isolates in contrast to less than $30 \%$ for all human isolates (Table 5), demonstrating that fish isolates were more virulent to tilapia than human isolates. GBS can infect diverse fish species and cause economic loss in fish farming. Therefore, vaccine is needed to prevent GBS 
infection. Recently, a vaccine strain with a truncated surface immunogenic protein (tSip) has been constructed against GBS infection [42]. In this study, the fish pulsotype Ia isolate 912 can be a vaccine candidate for tilapia due to low mortality.

The differences in symptom and mortality rate between human and fish isolates are possibly due to growth temperature and genetic differences. Recently, genome analysis of GBS determined more than 15 possible virulence genes homologous to genes pathogenic to human [43]. As virulence factor, $\beta$-hemolysin of GBS serotype Ia isolate is involved in the survival in the human macrophage THP-1 cell and enhance the tumor necrosis factor- $\alpha$ release [44]. Furthermore, host factors may also play important role in the defense of pathogen infection. In tilapia, hepcidin (TH) 1-5 can increase resistance to bacteria pathogens through modulation of related cytokines [45] and an increase of T-cell receptor expression of tilapia plays a role in response to GBS infection [46].

\section{Conclusions}

GBS isolates were the pathogens to bass, mullet, and tilapia and increased the resistance to antimicrobials used in human. ST types, pulsotypes and pathogenesis of GBS serotype Ia isolates differed between human and fish isolates, implying impossible transmission between human and fish in this study. The genes on the deletion fragment and plasmid of serotype Ia fish isolates may be responsible for the GBS virulence to tilapia.

\section{Additional files}

Additional file 1: Bacterial species, primer sequences and PCR product size. Primers used to differentiate four bacterial species. (DOCX $34 \mathrm{~kb}$ )

\section{Abbreviations}

CGMH, Chiayi Chang Gung Memorial Hospital; CLSI, Clinical and Laboratory Standards Institute; GBS, group B Streptococcus; MLST, multilocus sequence type; PFGE, pulsed-field gel electrophoresis; ST, sequence type

\section{Acknowledgments}

The authors would like to acknowledge funding from the Chiayi Chang-Gung Memorial Hospital (CMRPG6A0121) and Ministry of Science and Technology (NSC 102-2320-B-415-004).

\section{Authors' contributions}

CC supervised most aspects of this project and prepared the manuscript. PYH, IAT and CCL performed the experiments and data analysis. HMC and YHW performed human isolates collection and data analysis. C-CC designed and analyzed the experiments and edited manuscript. All authors read and approved the final manuscript.

\section{Authors' information}

Chishih Chu is a professor in the Department of Microbiology, Immunology, and Biopharmaceuticals, National Chiayi University. Pei-Yu Huang is an assistant in Chang-Gung Hospital. Hung-Ming Chen and Ying-Hsiang Wang are medical doctor in Department of Pediatric of Chang-Gung Hospital. I-An Tsai is an assistant of Che-Chun Chen. ChihCheng Lu is an student in National Chiayi
University. Che-Chun Chen is an associate professor in the Department of Aquatic Biosciences of National Chiayi University.

\section{Competing interests}

The authors declare that they have no competing interests.

\section{Author details}

1Department of Microbiology, Immunology, and Biopharmaceutics, National Chiayi University, Chiayi 60004, Taiwan, ROC. ${ }^{2}$ Department of Aquatic Biosciences, National Chiayi University, Chiayi 60004, Taiwan, ROC.

${ }^{3}$ Department of Pediatrics, Chang Gung Memorial Hospital, Chiayi, Taiwan, ROC.

Received: 16 April 2015 Accepted: 29 July 2016

Published online: 02 August 2016

\section{References}

1. Lee WT, Lai MC. High prevalence of Streptococcus agalactiae from vaginas of women in Taiwan and its mechanisms of macrolide and quinolone resistance. J Microbiol Immunol Infect. 2014; pii: S1684-1182(14)00055-3. doi: 10.1016/j.jmii.2014.03.002.

2. Mata Al, Gibello A, Casamayor A, Blanco MM, Domínguez L, FernándezGarayzábal JF. Multiplex PCR assay for detection of bacterial pathogens associated with warm-water streptococcosis in fish. App Environ Microbiol. 2004:70:3183-7.

3. Poyart C, Tazi A, Reglier-Poupet H, Billoët A, Tavares N, Raymond J, et al. Multiplex PCR assay for rapid and accurate capsular typing of group B Streptococci. J Clin Microbiol. 2007;45:1985-8.

4. Imperi M, Pataracchia M, Alfarone G, Baldassarri L, Orefici G, Creti R. A multiplex PCR assay for the direct identification of the capsular type (la to IX) of Streptococcus agalactiae. J Microbiol Meth. 2010;80:212-4.

5. Eldar A, Ghittino C, Asanta L, Bozzetta E, Goria M, Prearo M, et al. Enterococcus seriolicida is a junior synonym of Lactococcus garvieae, a causative agent of septicemia and meningoencephalitis in fish. Curr Microbiol. 1996;32:85-8.

6. Kang SH, Shin GW, Shin YS, Palaksha KJ, Kim YR, Yang HH, et al. Experimental evaluation of pathogenicity of Lactococcus garvieae in black rockfish (Sebastes schlegeli). J Vet Sci. 2004;5:387-90.

7. Hoshina T, Sano T, Morimoto Y. A streeptococcus pathogenic to fish. J Tokyo Univ Fish. 1958:44:57-68.

8. Eldar A, Bejerano Y, Livoff A, Horovitcz A, Bercovier H. Experimental streptococcal meningo-encephalitis in cultured fish. Vet Microbiol. 1995;43: 33-40.

9. Chen SC, Liaw LL, Su HY, Ko SC, Wu CY, Chaung HC, et al. Lactococcus garvieae, a cause of disease in grey mullet, Mugil cephalus L., in Taiwan. J Fish Dis. 2002;25:727-32.

10. Kusuda R, Kawai K, Salati F, Banner CR, Fryer UL. Enterococcus seriolicida sp. nov., a fish pathogen. Int J Syst Bacteriol. 1991;41:406-9.

11. Nho SW, Shin GW, Park SB, Jang HB, Cha IS, Ha MA, et al. Phenotypic characteristics of Streptococcus iniae and Streptococcus parauberis isolated from olive flounder (Paralichthys olivaceus). FEMS Microbiol Lett. 2009;293: 20-7.

12. Shewmaker PL, Camus AC, Bailiff T, Steigerwalt AG, Morey RE, Carvalho MG. Streptococcus ictaluri sp. nov., isolated from channel catfish Ictalurus punctatus broodstock. Int J Syst Evol Microbiol. 2007;57:1603-6.

13. Buchanan JT, Colvin KM, Vicknair MR, Patel SK, Timmer AM, Nizet V. Strainassociated virulence factors of Streptococcus iniae in hybrid-striped bass. Vet Microbiol. 2008:131:145-53.

14. Kawanishi M, Kojima A, Ishihara K, Esaki H, Kijima M, Takahashi T, et al. Drug resistance and pulsed-field gel electrophoresis patterns of Lactococcus garvieae isolates from cultured Seriola (yellowtail, amberjack and kingfish) in Japan. Lett App Microbiol. 2005;40:322-8.

15. Hung SW, Wang SL, Tu CY, Tsai YC, Chuang ST, Shieh MT, et al. Antibiotic susceptibility and prevalence of erythromycin ribosomal methylase gene, erm(B) in Streptococcus spp. Vet J. 2008:176:197-204.

16. Florindo C, Viegas S, Paulino A, Rodrigues E, Gomes JP, Borrego MJ. Molecular characterization and antimicrobial susceptibility profiles in Streptococcus agalactiae colonizing strains: association of erythromycin resistance with subtype III-1 genetic clone family. Clin Microbiol Infect. 2010; 46:1458-63 
17. Janapatla RP, Ho YR, Yan JJ, Wu HM, Wu JJ. The prevalence of erythromycin resistance in group $B$ streptococcal isolates at a university hospital in Taiwan. Microb Drug Resist. 2008;14:293-7.

18. Kayansamruaj P, Pirarat N, Katagiri T, Hirono I, Rodkhum C. Molecular characterization and virulence gene profiling of pathogenic Streptococcus agalactiae populations from tilapia (Oreochromis sp.) farms in Thailand. J Vet Diagn Invest. 2014;19(26):488-95.

19. van der Mee-Marquet N, Domelier AS, Salloum M, Violette J, Arnault L, Gaillard N, et al. Molecular characterization of temporally and geographically matched Streptococcus agalactiae strains isolated from food products and bloodstream infections. Foodborne Path Dis. 2009;6:1177-83.

20. Bowater RO, Forbes-Faulkner J, Anderson IG, Condon K, Robinson B, Kong F, et al. Natural outbreak of Streptococcus agalactiae (GBS) infection in wild giant Queensland grouper, Epinephelus lanceolatus (Bloch), and other wild fish in northern Queensland. Australia J Fish Dis. 2012:35:173-86.

21. Banai M, LeBlanc DJ. Genetic, molecular, and functional analysis of Streptococcus faecalis R plasmid pJH1. J Bacteriol. 1983;155:1094-104

22. Christie PJ, Dunny GM. Identification of regions of the Streptococcus faecalis plasmid pCF-10 that encode antibiotic resistance and pheromone response functions. Plasmid. 1986;15:230-41.

23. Sedgley CM, Lee EH, Martin MJ, Flannagan SE. Antibiotic resistance gene transfer between Streptococcus gordonii and Enterococcus faecalis in root canals of teeth Ex Vivo. J Endod. 2008;34:570-4.

24. Mian GF, Godoy DT, Leal CA, Yuhara TY, Costa GM, Figueiredo HC. Aspects of the natural history and virulence of S. agalactiae infection in Nile tilapia. Vet Microbiol. 2009;136:180-3.

25. Kayansamruaj P, Pirarat N, Hirono I, Rodkhum C. Increasing of temperature induces pathogenicity of Streptococcus agalactiae and the up-regulation of inflammatory related genes in infected Nile tilapia (Oreochromis niloticus). Vet Microbiol. 2014;172:265-71.

26. Wang YH, Su LH, Hou JN, Yang TH, Lin TY, Chu C, Chiu CH. Group B streptococcal disease in nonpregnant patients: emergence of highly resistant strains of serotype lb in Taiwan in 2006 to 2008. J Clin Microbiol. 2010:48:2571-4.

27. Wang YH, Chen CL, Hou JN, Wang YR, Lin TY, Wang MH, et al. Serotype distribution and resistance genes associated with macrolide and fluoroquinolone resistance in Streptococcus agalactiae isolates from a hospital in Southern Taiwan. Biomed J. 2015;38:215-20.

28. Liu G, Zhang W, Lu C. Comparative genomics analysis of Streptococcus agalactiae reveals that isolates from cultured tilapia in China are closely related to the human strain A909. BMC Genomics. 2013;14:775.

29. Chiu SY. Molecular typing and antimicrobial susceptibility testing of Streptococcus-like bacteria isolated. Chiayi, Taiwan: Department of Veterinary Medicine National Chiayi University Master Thesis; 2008. p. 1-89.

30. Clinical and laboratory Standerds Institute. Performance standards for antimicrobia disk susceptibility tests; approved standard-eleventh edtion. CLSI document: MO2-A11. Wayne Pennsylvania 19087, USA: Clinical and laboratory standards institute; 2012.

31. Kado Cl, Liu ST. Rapid procedure for detection and isolation of large and small plasmids. J Bact. 1981;145:1365-3.

32. Tenover FC, Arbeit RD, Goering RV, Mickelsen PA, Murray BE, Persing DH, Swaminathan B. Interpreting chromosomal DNA restriction patterns produced by pulsed-field gel electrophoresis: criteria for bacterial strain typing. J Clin Microbiol. 1995;33:2233-9.

33. Jones N, Bohnsack JF, Takahashi S, Oliver KA, Chan MS, Kunst F, et al. Multilocus sequence typing system for group B streptococcus. J Clin Microbiol. 2003;41:2530-6.

34. Elliott J, Facklam RR, Richter CB. Whole-cell protein patterns of nonhemolytic group B, type $\mathrm{Ib}$, Streptococci isolated from humans, mice, cattle, frogs, and fish. J Clin Microbiol. 1990;28:628-30.

35. Evans JJ, Bohnsack JF, Klesius PH, Whiting AA, Garcia JC, Shoemaker CA, et al. Phylogenetic relationships among Streptococcus agalactiae isolated from piscine, dolphin, bovine and human sources: a dolphin and piscine lineage associated with a fish epidemic in Kuwait is also associated with human neonatal infections in Japan. J Med Microbiol. 2008;57:1369-76.

36. Sukhnanand S, Dogan B, Ayodele MO, Zadoks RN, Craver MP, Dumas NB, et al. Molecular subtyping and characterization of bovine and human Streptococcus agalactiae isolates. J Clin Microbiol. 2005;43:1177-86.

37. Delannoy CM, Crumlish M, Fontaine MC, Pollock J, Foster G, Dagleish MP, et al. Human Streptococcus agalactiae strains in aquatic mammals and fish. BMC Microbiol. 2013;13:41.
38. Kimura K, Wachino J, Kurokawa H, Suzuki S, Yamane K, Shibata N, Arakawa Y. Practical disk diffusion test for detecting group B streptococcus with reduced penicillin susceptibility. J Clin Microbiol. 2009;47:4154-7.

39. Pereira UP, Mian GF, Oliveira IC, Benchetrit LC, Costa GM, Fiqueiredo HC Genotyping of Streptococcus agalactiae strains isolated from fish, human and cattle and their virulence potential in Nile tilapia. Vet Microbiol. 2010; 140:186-92.

40. Hernández E, Figueroa J, Iregui C. Streptococcosis on a red tilapia, Oreochromis sp., farm: a case study. J Fish Dis. 2009;32:247-52.

41. Evans JJ, Klesius PH, Pasnik DJ, Bohnsack JF. Human Streptococcus agalactiae isolate in Nile tilapia (Oreochromis niloticus). Emerg Infect Dis. 2009;15:774-5.

42. He Y, Wang KY, Xiao D, Chen DF, Huang L, Liu T, et al. A recombinant truncated surface immunogenic protein (tSip) plus adjuvant FIA confers active protection against Group B streptococcus infection in tilapia. Vaccine. 2014:32:7025-32

43. Lin FP, Lan R, Sintchenko V, Gilbert GL, Kong F, Coiera E. Computational bacterial genome-wide analysis of phylogenetic profiles reveals potential virulence genes of Streptococcus agalactiae. PLoS One. 2011;6:e17964.

44. Sagar A, Klemm C, Hartjes L, Mauerer S, van Zandbergen G, Spellerberg B. The $\beta$-hemolysin and intracellular survival of Streptococcus agalactiae in human macrophages. PLoS One. 2013;8:e60160.

45. Peng KC, Pan CY, Chou HN, Chen JY. Using an improved Tol2 transposon system to produce transgenic zebrafish with epinecidin-1 which enhanced resistance to bacterial infection. Fish Shellfish Immun. 2010;28:905-17.

46. Nithikulworawong N, Yakupitiyag A, Rakshit S. Molecular characterization and increased expression of the Nile tilapia, Oreochromis niloticus (L.), T-cell receptor beta chain in response to Streptococcus agalactiae infection. J Fish Dis. 2012:35:343-58.

\section{Submit your next manuscript to BioMed Central and we will help you at every step:}

- We accept pre-submission inquiries

- Our selector tool helps you to find the most relevant journal

- We provide round the clock customer support

- Convenient online submission

- Thorough peer review

- Inclusion in PubMed and all major indexing services

- Maximum visibility for your research

Submit your manuscript at www.biomedcentral.com/submit

Biomed Central 